\title{
PENERAPAN PROBLEM BASED LEARNING (PBL) DALAM MENINGKATKAN MINAT BELAJAR MATEMATIKA PADA MAHASISWA PGSD UAD SEMESTER I TH. 2016/2017
}

\author{
Meita Fitrianawati \\ Pendidikan Guru Sekolah Dasar, Universitas Ahmad Dahlan \\ Email: meita.fitrianawati@pgsd.uad.ac.id
}

\begin{abstract}
Abstrak
This study aims to determine the increased interest in learning mathematics in the first semester students PGSD UAD by using problembased learning (PBL). This type of research is a classroom action research (PTK). The action given is a two-cycle PBL learning. The subject of the study is the first semester student of C PGSD UAD in the academic year 2016/2017 consisting of 59 students. Data analysis technique used is descriptive analysis.

The result of research shows that the value of mathematics student interest in cycle I reach $13.59 \%$ in very high category, $23,73 \%$ in high category, $28,81 \%$ in high enough category, $25,42 \%$ in low category. This result has not reached the target to be achieved. Therefore, it is followed by cycle II. In the second cycle, the students' interest in mathematics score reached $25.42 \%$ in very high category, $54.24 \%$ in the high category, and $20.34 \%$ in the medium category. This study concludes that there is an increase in student interest in mathematics by using PBL in the first semester of PGSD UAD.
\end{abstract}

\section{Pendahuluan}

Pendidikan merupakan salah satu upaya untuk membangun dan meningkatkan mutu sumber daya manusia menuju era globalisasi yang penuh dengan tantangan sehingga disadari bahwa pendidikan sesuatu yang sangat penting bagi setiap individu. Oleh karena itu kegiatan pendidikan tidak dapat diabaikan begitu saja, terutama dalam memasuki era persaingan yang semakin ketat, tajam, berat pada abad melinium ini (Rivai dan Murni, 2010:1).

Peran pendidikan tersebut diupayakan agar setiap individu bisa mengembangkan kemampuan dan keterampilan yang dimilikinya. Kemampuan dan keterampilan tersebut bisa berupa intellectual skill, problem solving skill, communication skill dan lain sebagainya. Rivai dan Murni (2010:1) menambahkan bahwa keterampilan yang dikembangkan dalam dunia pendidikan berupa physical skill, intellectual skill, emotional/social skill, managerial skill, dan lain-lain.

Kurikulum merupakan salah satu kunci utama dalam proses kemajuan pendidikan. Kurikulum akan menentukan arah dan tujuan suatu pendidikan yang ingin dicapai. Sukmadinata (2011: 14) menjelaskan sebagai berikut,

Kurikulum mempunyai kedudukan sentral dalam seluruh proses pendidikan. Kurikulum mengarahkan segala bentuk aktifitas pendidikan demi tercapainya tujuan-tujuan pendidikan. Kurikulum juga merupakan suatu rencana pendidikan, memberikan pedoman dan pegangan tentang jenis, lingkup dan urutan isi, serta proses pendidikan.

Mengutip dari pendapat di atas, dapat dikatakan bahwa kurukulum memiliki peran utama dalam mewujudkan pendidikan yang berkualitas, sehingga jika dalam penyusunan kurikulum terjadi kegagalan, maka tujuan 
dari pendidikan tidak akan bisa terwujud. Kurikulum yang tidak dirancang sesuai dengan pedoman dan pegangan yang telah ditetapkan dapat membuat tujuan dan arah pendidikan menjadi tidak jelas.

Kurikulum 2013 adalah salah satu upaya pemerintah untuk memperbaiki sistem pendidikan. Pada UU No. 20 tahun 2003 tentang Sistem Pendidikan Nasional diayatakan bahwa Pendidikan adalah usaha sadar dan terencana untuk mewujudkan suasana belajar dan proses pembelajaran agar peserta didik secara aktif mengembangkan potensi dirinya untuk memiliki kekuatan spiritual keagamaan, pengendalian diri, kepribadian, kecerdasan, akhlak mulia, serta keterampilan yang diperlukan dirinya, masyarakat, bangsa, dan negara.

Dalam upaya mewujudkan suasana belajar dan proses pembelajaran seperti yang tercantum dalam Undang-undang No. 20 tahun 2003 tersebut, pemerintah melalui Peraturan menteri pendidikan RI nomor 65 tahun 2013 tentang standar proses, mengemukakan karakteristik pembelajaran sesuai dengan Standar Kompetensi Lulusan (SKL), sasaran pembelajaran mencakup pengembangan ranah sikap, pengetahuan, dan keterampilan yang dielaborasi untuk setiap satuan pendidikan. Ketiga ranah kompetensi tersebut memiliki lintasan perolehan (proses psikologis) yang berbeda. Sikap diperoleh melalui aktivitas "menerima, menjalankan, menghargai, menghayati, dan mengamalkan". Pengetahuan diperoleh melalui aktivitas "mengingat, memahami, menerapkan, menganalisis, mengevaluasi, mencipta. Keterampilan diperoleh melalui aktivitas "mengamati, menanya, mencoba, menalar, menyaji, dan mencipta".

Upaya dalam mengembangkan ketiga ranah di atas yaitu sikap, pengetahuan dan keterampilan tersebut perlu dilakukan peningkatan kualitas pembelajaran baik dari segi penguasaan materi, penggunaan metode, penggunaan media maupun pengelolaan kelas yang kondusif. Ketiga ranah tersebut diaplikasikan pada semua jenjang pendidikan dan mata pelajaran yang tercantum dalam peraturan pemerintah.
Salah satu pembelajaran yang menjadi sorotan masyarakat saat ini adalah mata pelajaran matematika yang menurut beberapa mahasiswa dianggap sebagai materi yang sulit. Dalam Permendikbud No 58 Tahun 2013 tentang kurikulum dijelaskan bahwa,

Mata pelajaran matematika perlu diberikan kepada semua peserta didik mulai dari sekolah dasar, untuk membekali peserta didik dengan kemampuan berpikir logis, analitis, sistematis, kritis, inovatif dan kreatif, serta kemampuan bekerjasama.

Pentingnya pembelajaran matematika diberikan baik di sekolah maupun perguruan tinggi menuntut pada pentingnya pengembangan prestasi belajar matematika. pengembangan prestasi tersebut bisa berupa prestasi belajar kognitif, afektif dan psikomotorik. Dengan tidak mengabaikan pengembangan prestasi belajar yang lain, peningkatan prestasi belajar kognitif merupakan salah satu komponen utama dalam melihat kualitas suatu pembelajaran.

Lebih lanjut dalam Peraturan Menteri Pendidikan nasional No. 58 tahun 2013 tersebut juga disebutkan beberapa kompetensi yang harus dicapai dalam mata pelajaran matematika. Kompetensi tersebut diantaranya yaitu,

Memiliki sikap menghargai kegunaan matematika dalam kehidupan, yaitu memiliki rasa ingin tahu, perhatian, dan minat dalam mempelajari matematika, serta sikap ulet dan percaya diri dalam pemecahan masalah.

Dengan memperhatikan standar kompetensi matematika tersebut di atas, salah satu aspek afektif yang perlu diperhatikan yakni aspek minat belajar dalam mempelajari matematika.

Collette \& Chiapetta (1994: 74) mengemukakan bahwa "interest is defined as curiosity or fascination for an idea or even the engages attention", dimana minat diartikan adalah rasa keingintahuan atau daya tarik pada suatu pemikiran atau kejadian yang melibatkan perhatian serta 
menggunakannya untuk sebuah ide atau peristiwa.

Menurut Hilgard ((1991: 57) "Interest is persisting tendency to pay attention to end enjoy some activity and content". yang artinya, minat adalah kecenderungan yang kuat untuk memperhatikan hingga akhir, dan menikmati beberapa kegiatan serta memiliki rasa puas. Sedangkan menurut Elliot,et.al. (2000: 349) mengungkapkan bahwa "interest is similar and related to curiosity. Interest is an enduring characteristic expressed by a relationship between a person and particular activity or object" yang berarti bahwa minat terkait dengan rasa ingin tahu. Minat merupakan karakteristik yang diungkapkan oleh hubungan antara seseorang dan kegiatan atau objek tertentu.

Minat belajar mahasiswa akan tumbuh dan terpelihara apabila kegiatan belajar mengajar dilaksanakan secara bervariasi dan dihadapkan pada kehidupan nyata. Selama ini umumnya mahasiswa hanya menghafalkan rumus untuk menyelesaikan soal-soal matematika. Karena matematika bersifat abstrak dan membutuhkan pemahaman konsep-konsep, maka mahasiswa menyikapinya secara berbedabeda, mungkin menerima dengan baik atau sebaliknya. Mahasiswa yang mempunyai minat belajar terhadap matematika cenderung tertarik dan berusaha mempelajari dan mendalami matematika. Minat belajar sangat penting dimiliki mahasiswa, terutama terhadap pelajaran matematika karena minat belajar mahasiswa terhadap matematika berhubungan langsung dengan prestasi belajar matematika.

Tujuan pembelajaran akan tercapai apabila perencanaan dan metode yang digunakan dapat mempengaruhi potensi dan kemampuan yang dimiliki peserta didik dan keberhasilan tersebut akan tercapai apabila peserta didik dilibatkan dalam proses berpikirnya. Salah satu pendekatan pembelajaran yang melibatkan mahasiswa aktif dan dilibatkan proses berpikirnya adalah melalui pembelajaran PBL.

PBL merupakan model pembelajaran yang berorientasi pada kerangka kerja teoritik konstruktivisme. Dalam model PBL fokus pembelajaran ada pada masalah yang dipilih sehingga mahasiswa tidak saja mempelajari konsep-konsep yang berhubungan dengan masalah tetapi juga metode ilmiah untuk memecahkan masalah tersebut.

Arends (2007: 43) menyatakan bahwa esensinya PBL menyuguhkan berbagai situasi bermasalah yang autentik dan bermakna kepada mahasiswa, yang dapat berfungsi sebagai batu loncatan untuk investigasi dan penyelidikan. PBL dirancang untuk membantu siswa mengembangkan keterampilan berpikir dan keterampilan menyelesaikan masalah, mempelajari peranperan orang dewasa dan menjadi pelajar yang mandiri. Oleh sebab itu, mahasiswa tidak saja harus memahami konsep yang relevan dengan masalah yang menjadi pusat perhatian tetapi juga memperoleh pengalaman belajar yang berhubungan dengan ketrampilan menerapkan metode ilmiah dalam pemecahan masalah dan menumbuhkan pola berpikir kritis kreatif siswa.

PBL dimulai oleh adanya masalah yang dalam hal ini dapat dimunculkan oleh mahasiswa, kemudian mahasiswa memperdalam pengetahuannya tentang apa yang mereka telah ketahui dan apa yang mereka perlu ketahui untuk memecahkan masalah tersebut. Mahasiswa dapat memilih masalah yang dianggap menarik untuk dipecahkan sehingga mereka terdorong berperan aktif dalam belajar serta minat belajar mereka menjadi meningkat. Hal ini sesuai diungkapkan Tan (2003:13) menggarisbawahi bahwa "it is not how much content we disseminate in our classrooms but how we engage students' motivation and independent learning that is important. In $P B L$, the design of real word problem scenarios is crucial and the problems act as triggers for self-directed and collaborative learning."

Ada hal yang berbeda yang akan kita jumpai di dalam aplikasi pembelajaran matematika secara praktik di lapangan yang menunjukan bahwa terjadi inkonsistensi 
pembelajaran terhadap acuan pijakan yang sudah ditentukan dalam konstitusi. Berdasarkan pengalaman peneliti selama melakukan observasi lapangan di kelas $\mathrm{C}$ semester I PGSD UAD melihat bahwa pembelajaran matematika masih monoton dalam arti bahwa pola pengajaran dari hari ke hari selalu sama sehingga pembelajaran matematika menjadi membosankan.

Hal tersebut sesuai dikuatkan dengan wawancara kepada mahasiswa bahwa, dalam pembelajaran matematika, biasanya peneliti selalu memberikan contoh soal tertutup dan cara menyelesaikannya sebelum memberikan latihan dan tugas rumah kepada mahasiswa. Hal ini mengakibatkan mahasiswa menjadi tidak tertantang lagi dengan soal-soal latihan ataupun tugas rumah yang diberikan oleh peneliti. Hal lain yang terjadi adalah pola perhatian peneliti yang tidak merata kepada semua mahasiswa, dalam arti peneliti lebih banyak memberikan perhatian lebih kepada anak-anak yang pintar saja sehingga berakibat pada timbulnya sikap apatis dari mahasiswa yang kurang mendapat perhatian peneliti sehingga menimbulkan minat belajar mahasiswa kurang.

Kenyataan di lapangan juga menunjukkan bahwa selama ini mahasiswa belum pernah mengembangkan pembelajaran berbasis masalah untuk meningkatkan minat belajar mahamahasiswa. Berdasarkan hasil observasi yang dilakukan oleh peneliti di, teridentifikasi bahwa minat mahasiswa terhadap matematik, khususnya kelas C masih kurang. Hal ini dibuktikan dengan tidak sedikit mahasiswa yang terlihat mengalami kebosanan saat pembelajaran matematika berlangsung. Selain itu masih banyak keluhan dari mahasiswa tentang rendahnya kemampuan mahasiswa dalam aplikasi matematika, khususnya penerapan di dalam kehidupan sehari-hari atau kehidupan nyata. Sementara itu, hal ini jelas sangat berakibat buruk bagi perkembangan pendidikan matematika ke depan. Oleh karena itu, perubahan metode pembelajaran matematika yang menyenangkan harus menjadi prioritas utama. Hasil empiris di atas jelas merupakan suatu permasalahan yang merupakan faktor penting dalam mewujudkan tujuan pembelajaran matematika sesuai yang diamanatkan dalam kurikulum pendidikan matematika. Hal ini didukung oleh observasi awal dengan membagikan angket tentang minat belajar, dari hasil angket minat belajar mahasiswa dalam kategori cukup tinggi atau bisa dikatakan sedang dari lima skala yang digunakan yaitu sangat tinggi, tinggi, cukup tinggi, rendah dan sangat rendah.

Mengingat pentingnya matematika serta berdasarkan permasalahan yang telah diuraikan, maka perlu adanya perlakuan khusus agar matematika tidak lagi menjadi pelajaran yang membosankan. Selain itu peneliti dalam mengajar matematika perlu menerapkan inovasi dalam pembelajaran.

Oleh karena itu, sebagai kesimpulan atas keseluruhan latar belakang, adapun judul penelitian ini adalah "Penerapan Problem Based Learning (PBL) Dalam Meningkatkan Minat Belajar Matematika Pada Mahasiswa PGSD UAD Semester I".

\section{Metode Penelitian}

Subjek dalam penelitian ini adalah mahasiswa kelas $\mathrm{C}$ semester I yang terdiri dari 59 mahasiswa. Alasan pemilihan kelas $\mathrm{C}$ adalah karena dari 3 kelas yang ada, kelas $\mathrm{C}$ merupakan kelas yang prestasinya paling rendah sehingga perlu dilakukan penelitian tindakan untuk mengatasi masalah tersebut. Penelitian ini merupakan penelitian tindakan kelas (PTK) yang terdiri dari empat tahap yaitu perencanaan (planning), tindakan (action), observasi (observing) dan refleksi (reflecting). Adapun teknik pengumpulan data dalam penelitian ini adalah dengan metode tes, angket dan observasi. Metode tes digunakan untuk mengumpulkan data prestasi belajar kognitif mahasiswa, metode angket digunakan untuk mengumpulkan data minat belahajar mahasiswa sedangkan metode observasi digunakan untuk mengumpulkan data keterlaksanan pembelajaran dengan menggunakan PBL baik keterlaksanaan pembelajaran oleh dosen maupun aktivitas mahasiswa.

Teknik analisis data yang digunakan dalam penelitian ini adalah analisis 
deskriptif. Analisis deskriptif untuk mendeskripsikan keadaan mahasiswa pada setiap siklus yang dilaksanakan. Pemberian angket pada siklus 1 dan siklus selanjutnya dibandingkan untuk mengetahui adanya peningkatan minat balajar mahasiswa atau tidak. Penskoran untuk angket minat mahasiswa dilakukan menggunakan skala Likert dengan membuat interval menjadi 5 kriteria yaitu sangat tinggi, tinggi, cukup tinggi, rendah dan sangat rendah. Penskoran untuk skala minat belajar mahasiswa pada penelitian ini memiliki rentang antara 30 sampai dengan 150, karena nilai terendah dalam penskoran angket adalah 30 dan nilai tertinggi adalah 150. Untuk menentukan kriteria hasil pengukurannya digunakan klasifikasi berdasarkan rata-rata ideal (Mi) dan standar deviasi ideal $(\mathrm{Si}) . \mathrm{Mi}=(30+$ $150) / 2=90$ dan $\mathrm{Si}=(150-30) / 6=20$.

Tabel 1. Kategorisasi Minat Belajar Mahasiswa

\begin{tabular}{cccc} 
No & Interval & Skor $(\mathrm{X})$ & Kriteria \\
\hline 1 & $\mathrm{Mi}+1,5 \mathrm{Si}<\mathrm{X} \leq \mathrm{Mi}+3 \mathrm{Si}$ & $120<\mathrm{X} \leq 150$ & $\begin{array}{c}\text { Sangat } \\
\text { Tinggi }\end{array}$ \\
& & & . \\
\hline 2 & $\mathrm{Mi}+0,5 \mathrm{Si}<\mathrm{X} \leq \mathrm{Mi}+1,5 \mathrm{Si}$ & $100<\mathrm{X} \leq 120$ & Tinggi \\
\hline 3 & $\mathrm{Mi}-0,5 \mathrm{Si}<\mathrm{X} \leq \mathrm{Mi}+0,5 \mathrm{Si}$ & $80<\mathrm{X} \leq 100$ & $\begin{array}{c}\text { Cukup } \\
\text { Tinggi }\end{array}$ \\
\hline 4 & $\mathrm{Mi}-1,5 \mathrm{Si}<\mathrm{X} \leq \mathrm{Mi}-0,5 \mathrm{Si}$ & $60<\mathrm{X} \leq 80$ & Rendah \\
\hline 5 & $\mathrm{Mi}-3 \mathrm{Si} \leq \mathrm{X} \leq \mathrm{Mi}-1,5 \mathrm{Si}$ & $30 \leq \mathrm{X} \leq 60$ & $\begin{array}{c}\text { Sangat } \\
\text { Rendah }\end{array}$ \\
& & &
\end{tabular}

Indikator minat belajar mahasiswa dalam pembelajaran matematika melalui PBL meningkat dari siklus I ke siklus selanjutnya sampai minimal memenuhi kategori tinggi dengan minimal skor untuk kategori tinggi $40 \%$ dan kategori sangat tinggi $60 \%$ dari skor minimal.

Pelaksanaan pembelajaran dengan model pembelajaran berbasis masalah dikatakan berhasil jika lebih dari $75 \%$ sesuai dengan rancangan yang telah disusun. Terlaksananya pembelajaran dengan pembelajaran berbasis masalah ditunjukkan dengan kegiatan berikut:

a. Mengorientasikan mahasiswa pada masalah, yaitu peneliti menjelaskan topik pembelajaran dan memotivasi mahasiswa. Pada langkah ini peneliti meminta mahasiswa untuk mencermati masalah yang diberikan. Peneliti memberikan penjelasan terhadap masalah tersebut jika ada kelompok yang belum paham.

b. Mengorganisasikan mahasiswa untuk belajar, yaitu mahasiswa diminta berkelompok untuk selanjutnya berdiskusi menyelesaikan masalah. Pengelompokan mahasiswa dengan cara berpasangan dengan teman satu meja. Hal ini bertujuan agar semua anggota kelompok dapat ikut berperan aktif dalam menyelesaikan masalah.

c. Membimbing penyelidikan individu maupun kelompok, yaitu peneliti mendorong mahasiswa untuk mengembangkan pemikirannya dalam menyelesaikan masalah dengan menggunakan langkah penyelesaian masalah yang benar. Peneliti memberikan bimbingan kepada kelompok. yang belum paham, sedangkan kelompok yang sudah paham diberi kebebasan oleh peneliti untuk menggunakan kemampuan yang dimiliki dalam menyelesaikan masalah..

d. Mengembangkan dan menyajikan hasil karya, yaitu mahasiswa diminta untuk mengungkapkan gagasan dan penyelesaian yang telah diperoleh. Setiap kelompok diminta untuk menyajikan hasil karya dengan mempresentasikan jawaban yang telah diperoleh.

e. Menganalisis dan mengevaluasi proses pemecahan masalah, yaitu peneliti bersama mahasiswa mengevaluasi penyelesaian masalah yang telah dikerjakan pada siklus II, sebagian besar mahasiswa sudah berani menanggapi kelompok lain dan sering terjadi diskusi kecil saat presentasi berlangsung.

\section{Hasil dan Pembahasan}

\section{Hasil Penelitian Siklus I}

Pembelajaran pada siklus I berlangsung dalam dua pertemuan. Masing-masing pertemuan berlangsung 2 x 50 menit. Sedangkan evaluasi berlangsung selama 40 menit pada pertemuan kedua. Materi yang dibahas pada siklus I meliputi pengertian himpuan dan relasi himpunan

Pada pertemuan pertama materi yang diberikan adalah mengenal himpunan. 
Kegiatan pada siklus I terdiri dari 4 tahap yaitu sebagai berikut.

a. Tahap Perencanaan Tindakan

1) Mengkaji langkah-langkah dalam pembelajaran PBL.

2) Menyusun perangkat pembelajaran siklus I seperti SAP dan LKM.

3) Menyiapkan lembar observasi kegiatan siklus I

4) Menyiapkan soal evaluasi siklus I beserta kunci jawabannya

5) Menyiapkan pedoman pensekoran soal evaluasi siklus I

6) Menyiapkan angket untuk mengukur minat belajar mahasiswa pada siklus I

b. Tahap Pelaksanaan Tindakan

1)Pertemuan pertama

Kegiatan pembelajaran siklus 1 pertemuan pertama dilaksanakan kegiatan tersebut perangkat pembelajaran berupa silabus, SAP, LKM dan tes individu sudah disiapkan. Selesai memberikan arahan kepada mahasiswa, peneliti langsung meminta mahasiswa untuk membentuk kelompok sendiri yang terdiri dari 12 kelompok sehingga masing-masing kelompok terdiri dari 5 mahasiswa. Pada proses pembentukan kelompok tersebut, mahasiswa masih ribut dan bingung dalam membentuk kelompok sehingga waktu yang dibutuhkan untuk membentuk kelompok cukup lama. Dosen selanjutnya meminta mahasiswa untuk menulis anggota kelompoknya pada kertas dan menyerahkannya kepada peneliti. Setelah itu, memberikan soal pretes kepada mahasiswa dan mahasiswa secara antusias menjawab pretes tersebut secara individu, namun beberapa mahasiswa lain masih bingung dalam menyelesaikan soal tersebut, pelaksanaan pretest berlangsung selama \pm 40 menit.

Peneliti selanjutnya memberikan LKM 1 kepada masing-masing kelompok untuk diselesaikan dengan berdiskusdi pada kelompok masing-masing, tiap kelompok mengerjakan LKM 1 secara antusias dan kooperatif. Pada saat mengerjakan LKM 1 terlihat beberapa mahasiswa bekerja sama dan saling tanya jawab pada saat berdiskusi, akan tetapi beberapa kelompok juga terlihat masih ribut dan membicarakan hal lain diluar materi pada LKM 1. Peneliti juga memberikan bimbingan terbatas kepada masing-masing kelompok jika ada hal yang belum jelas dalam pengerjaan LKM 1 tersebut. Mahasiswa membutuhkan waktu yang cukup lama dalam mengerjakan LKM 1 tersebut sehingga belum ada satu kelompok yang menyelesaikan LKM 1 secara sempurna sehingga kegiatan presentasi kelompok tidak terlaksana dengan baik karena waktu pelajaran matematika sudah habis. Selanjutnya memberikan pengarahan kepada mahasiswa untuk perbaikanperbaikan pada pertemuan selanjutnya dengan mengurangi ribut dan lebih serius dalam bekerja sama pada masing-masing kelompok.

2)Pertemuan kedua

Kegiatan pembelajaran siklus 1 pertemuan kedua dilaksanakan dengan pada kegiatan tersebut perangkat pembelajaran berupa silabus, RPP, LKS dan tes individu sudah disiapkan. Sebelum memulai pembelajaran, peneliti mengajak mahasiswa untuk mempersapkan diri sebelum memulai pelajaran dengan mengajak mahasiswa untuk tenang dan mempersiapkan bahan pembelajaran yang akan digunakan. Pada penyampaian apersepsi, peneliti mengingat materi sebelumnya dengan mengulas kembali contoh pada LKM pertemuan sebelumnya. Selanjutnya peneliti menyampaikan tujuan pembelajaran dengan menyebutkan kepada mahasiswa apa yang bisa diperoleh mahasiswa dalam pembelajaran tersebut. Selanjutnya peneliti memberikan informasi sedikit mengenai relasi pada himpunan yang nantinya akan mereka kerjakan pada LKM yang sudah disiapkan, peneliti meminta mahasiswa untuk bertanya jika ada yang belum jelas dari penjelasan materi tersebut. Terlihat beberapa mahasiswa bertanya tentang materi yang belum jelas sehingga peneliti 
memberikan penjelasan lebih detail mengenaioperasi pada himpunan. Setelah itu, peneliti menginstruksikan kepada masingmasing kelompok untuk mendiskusikan LKM 2 yang sudah mereka dapatkan. Sebelum memulai diskusi, peneliti menyampaikan komponen-komponen penilaian dalam diskusi kelompok. Terlihat mahasiswa berdiskusi secara tenang dan saling tanya jawab satu sama lainnya. Peneliti berkeliling untuk melihat proses terjadinya diskusi sambil memberikan bantuan terbatas kepada mahasiswa dalam kelompok jika ada sesuatu yang kurang jelas dari LKM 2 tersebut. Setelah selesai mendiskusikan LKM 2, peneliti meminta beberapa kelompok untuk mempresentasikan hasil diskusi mereka di tempat masingmasing dengan cara berdiri, sementara kelompok lain memperhatikan presentasi kelompok tersebut, dalam presentasi tersebut tidak terjadi tanggapan dari kelompok lain.

Setelah selesai mempresentasikan hasil diskusi selanjutnya masing-masing mahasiswa diminta untuk kembali duduk. Peneliti bersama seluruh mahasiswa mengkroscek hasil kerja kelompok dan presentasi dari setiap kelompok serta membuat kesepakatan yang tepat mengenai materi yang dibahas. Setelah itu peneliti memberikan soal latihan yang harus dikerjakan secara individu oleh mahasiswa. Mahasiswa menggunakan waktu yang tersisa untuk menyelesaikan soal latihan yang diberikan peneliti secara individu, beberapa mahasiswa masih sulit untuk menerima instruksi dari peneliti, terlihat sebagian besar mahasiswa antusias meskipun beberapa masih seperti biasa. Setelah selesai mengerjakan soal tersebut, peneliti menutup pelajaran dan akan mengumumkan kepada mahasiswa tentang ulangan atau uji kompetensi dari materi pada pertemuan pertama dan kedua.

Dalam kegiatan pembelajaran siklus 1 pertemuan pertama dan kedua tersebut terdapat beberapa butir-butir instrument yang tidak tampak atau tidak baik, diantaranya sebagai berikut. a) Penggunaan alokasi waktu yang kurang baik sehingga beberapa kegiatan pembelajaran tidak terlaksana

b) Pelaksanaan presentasi kelompok tidak terlaksana dengan baik pada pertemuan pertama dan kurang maksimal pada pertemuan kedua.

c) Beberapa mahasiswa tidak mendengarkan dan memperhatikan penjelasan.

d) Mahasiswa membentuk kelompok secara kurang tertib.

Kekurangan-kekurangan yang terjadi pada siklus I selanjutnya dilakukan refleksi dengan peneliti untuk disusun perencanaan yang lebih baik dan sesuai dengan langkahlangkah pembelajaran dengan PBL.

c. Tahap Observasi

Berdasarkan lembar observasi, terdapat beberapa kekurangan dan hal-hal yang mendukung dalam pelaksanaan skenario pembelajaran siklus I.

Adapun kekurangan-kekurangan pada proses pembelajaran berdasarkan lembar observasi yaitu sebagai berikut.

1) Penggunaan alokasi waktu yang kurang baik sehingga beberapa kegiatan pembelajaran tidak terlaksana

2) Pelaksanaan presentasi kelompok tidak terlaksana pada pertemuan pertama dan kurang maksimal pada pertemuan kedua.

3) Beberapa mahasiswa tidak mendengarkan dan memperhatikan penjelasan peneliti.

4) Mahasiswa membentuk kelompok secara kurang tertib.

Setelah pembelajaran pada siklus I selesai, peneliti melakukan evaluasi dan memberikan angket minat belajar mahasiswa. Berikut disajikan rangkuman hasil evaluasi angket minat belajar mahasiswa. 
Tabel 2. Hasil Evaluasi Minat Belajar Mahasiswa Siklus I

\begin{tabular}{lcc} 
Keterangan & Jumlah & Persentase \\
Sangat Tinggi & 8 & $13,59 \%$ \\
\hline Tinggi & 14 & $23,73 \%$ \\
\hline Cukup Tinggi & 17 & $28,81 \%$ \\
\hline Rendah & 15 & $25,42 \%$ \\
\hline Sangat Rendah & 0 & $0 \%$ \\
\hline
\end{tabular}

Berdasarkan tabel di atas, terlihat bahwa minat belajar mahasiswa pada kategori sangat tinggi memiliki persentase $13,59 \%$, kategori tinggi memiliki persentase $23,73 \%$, kategori cukup tinggi memiliki presentase $28,81 \%$ dan kategori rendah memiliki persentase $25,42 \%$.

d. Tahap Refleksi

Berdasarkan hasil observasi dan diskusi dengan observer, kekurangankekurangan yang terdapat pada siklus I akan dilakukan tindakan perbaikan pada siklus II yaitu

1. Merencanakan alokasi waktu yang lebih efektif, dan alokasi waktu untuk menyampaikan materi harus efisien.

2. Mengoptimalkan pengelolaan kelas terutama saat berdiskusi.

3. Mengajak mahasiswa untuk lebih semangat dalam presentasi hasil diskusi kelompok.

4. Mengajak mahasiswa untuk membuat kesimpulan dari materi yang dipelajari.

\section{Hasil Penelitian Siklus II}

Proses pembelajaran pada siklus II berlangsung dalam dua pertemuan. Pertemuan berlangsung selama 2 x 50 menit. Sedangkan evaluasi berlangsung selama 50 menit pada pertemuan ketiga.

a. Tahap Pelaksanaan Tindakan

1)Pertemuan pertama

Kegiatan pembelajaran siklus 2 pertemuan pertama dengan kegiatan tersebut perangkat pembelajaran berupa SAP, LKM dan tes individu sudah disiapkan dan direvisi dari hasil refleksi pada siklus 1 .

Sebelum memulai pembelajaran, peneliti mengajak mahasiswa untuk mempersiapkan diri dan mempersiapkan bahan-bahan yang akan digunakan dalam proses pembelajaran. Selain itu peneliti juga mengajak mahasiswa untuk lebih tenang dalam mengikuti pembelajaran baik sebelum berkumpul dalam kelompok maupun saat kembali ketempat duduk masing-masing.

Proses pembelajaran dimulai dengan penyampaian apersepsi oleh peneliti dengan menyampaikan materi yang sebelumnya sudah dipelajari. Dalam kegiatan penyampaian apersepsi tersebut peneliti mengajak mahasiswa untuk bertanya jika ada hal yang belum jelas terkait materi sebelumnya dan beberapa mahasiswa bertanya mengenai operasi pada himpunan.

Selanjutnya peneliti juga tidak lupa menyampaikan tujuan pembelajaran yang ingin dicapai dalam pembelajaran pada hari tersebut dengan mengaitkan materi dan kehidupan sehari-hari. Kegiatan selanjutnya yang dilakukan peneliti adalah memberikan informasi terkait materi yang akan dipelajari pada saat itu. Sebelum diskusi dimulai, peneliti menginstruksikan kepada seluruh mahasiswa untuk bergabung kembali dengan kelompoknya, tidak lupa pula menyampaikan aturan-aturan dalam berdiskusi dan komponen penilaian dalam berdiskusi dan mahasiswa yang sudah berkumpul degan anggota kelompoknya memperhatikan penjelasan tersebut.

Selanjutnya peneliti membagikan LKM 3 kepada masing-masing mahasiswa dalam kelompok dan meminta mahasiswa untuk menyelesaikan LKM 3 tersebut dengan berdiskusi dengan anggota kelompoknya. Saat mendiskusikan LKM 3 suasana kelas lebih kondusif meskipun terdengar suarasuara dialog antar mahasiswa terkait dalam mendiskusikan LKM 3 tersebut. Peneliti juga berkeliling ke setiap kelompok untuk melihat proses jalannya diskusi dan memberikan bantuan terbatas kepada mahasiswa yang merasa belum jelas dalam menyelesaikan LKS 3 tersebut.

Setelah semua kelompok selesai mengerjakan, selanjutnya peneliti meminta beberapa kelompok untuk mempresentasikan hasil diskusi mereka di depan kelas. Pada kesempatan itu, peneliti memilih kelompok 3 saja yang mempresentasikan terlebih dahulu hasil diskusi mereka. Terlihat siswa 
memperhatikan presentasi dari beberapa kelompok tersebut, namun mahasiswa masih sulit untuk menanggapi persentasi dari teman-temannya.

Setelah kegiatan presentasi hasil diskusi tersebut, peneliti tidak lupa memberikan penghargaan berupa pujian kepada mahasiswa yang sudah berani mempresentasikan hasil diskusi mereka dan mengajak mahasiswa untuk lebih bersemangat lagi. Selanjutnya menuliskan latihan soal di papan tulis yang diselesaikan secara individu oleh setiap mahasiswa. Peneliti menggunakan waktu 15 menit untuk menyelesaikan soal latihan tersebut karena hanya terdiri dari 2 soal saja dan hasilnya mahasiswa mengerjakan soal latihan tersebut sesuai waktu yang telah ditentukan. Selanjutnya peneliti mengajak mahasiswa untuk membuat kesimpulan dari materi yang dipelajari pada hari tersebut dan menginformasikan kepada mahasiswa bahwa proses pembelajaran berikutnya akan dilaksanakan dengan berdiskusi. Setelah itu peneliti menutup pembelajaran dengan doa dan mengucapkan salam.

2) Pertemuan kedua

Kegiatan pembelajaran siklus 2 perangkat pembelajaran berupa LKM dan tes individu sudah disiapkan dan direvisi dari hasil refleksi pada siklus 1. Sebelum memulai pembelajaran, peneliti mengajak mahasiswa untuk mempersiapkan diri dan mempersiapkan bahan-bahan yang akan digunakan dalam proses pembelajaran. Selain itu peneliti juga mengajak mahasiswa untuk lebih tenang dalam mengikuti pembelajaran baik sebelum berkumpul dalam kelompok maupun saat kembali ketempat duduk masing-masing.

Proses pembelajaran dimulai dengan penyampaian apersepsi oleh peneliti dengan menyampaikan materi sebelumnya yaitu tentang operasi himpunan dalam masalah sehari-hari. Dalam kegiatan penyampaian apersepsi tersebut sesekali bertanya kepada mahasiswa tentang materi yang sebelumnya dusah dipelajari, juga menginstruksikan kepada mahasiswa untuk bertanya jika ada hal yang belum jelas terkait materi sebelumnya. Selanjutnya peneliti juga tidak lupa menyampaikan tujuan pembelajaran yang ingin dicapai dalam pembelajaran pada hari tersebut.

Kegiatan selanjutnya yang dilakukan peneliti adalah memberikan informasi terkait materi yang akan dipelajari pada saat itu yaitu operasi himpunan dalam permasalahan kehidupan sehari-hari. Peneliti juga mengajak mahasiswa untuk bertanya dan beberapa mahasiswa mengangkat tangan dan bertanya kepada peneliti terkait dengan materi yang dipelajari.

Setelah pemberian informasi tersebut dirasa sudah cukup, peneliti menginstruksikan mahasiswa berkumpul dengan anggota kelompoknya disertai dengan membawa bahan-bahan yang akan digunakan untuk berdiskusi nantinya. Sebelum diskusi dimulai, peneliti seperti biasa pada pertemuan sebelumnya tidak lupa menyampaikan aturan-aturan dalam berdiskusi dan komponen penilaian dalam berdiskusi dan mahasiswa yang sudah berkumpul dengan anggota kelompoknya memperhatikan penjelasan tersebut.

Selanjutnya peneliti membagikan LKM 4 kepada masing-masing mahasiswa dalam kelompok dan meminta mahasiswa untuk menyelesaikan LKM 4 tersebut dengan berdiskusi dengan anggota kelompoknya. Peneliti berkeliling melihat proses jalannya diskusi dan memberikan bantuan terbatas kepada mahasiswa yang merasa belum jelas dalam menyelesaikan LKM 4 tersebut. Waktu yang dibutuhkan untuk mendiskusikan LKM 4 tersebut tepat sesuai dengan waktu yang telah ditentukan, Masing-masing kelompok sudah selesai mendiskusikan LKM 4 dan selanjutnya peneliti meminta masing-masing kelompok untuk mempresentasikan hasil diskusi mereka. Pada saat persentasi kelompok, yang lain memperhatikan dan menyimak apa yang disampaikan oleh temannya sembari menyiapkan pertanyaan bila ada yang berbeda dengan hasil diskusi kelompok lain. Setelah kegiatan presentasi hasil diskusi tersebut, peneliti tidak lupa memberikan apresiasi kepada mahasiswa yang telah 
mempresentasikan hasil diskusi mereka dan mengajak mahasiswa untuk lebih bersemangat lagi. Selanjutnya peneliti memberikan soal yang diselesaikan secara individu dimana sebelumnya peneliti meminta mahasiswa untuk kembali duduk dan berpisah dari anggota kelompoknya. Peneliti menggunakan waktu 40 menit untuk menyelesaikan soal tersebut karena hanya terdiri dari 3 soal saja. Selanjutnya peneliti mengajak mahasiswa untuk membuat kesimpulan dari materi yang dipelajari pada hari tersebut dan menginformasikan kepada mahasiswa bahwa proses pembelajaran berikutnya akan dilaksanakan tes evaluasi. Setelah itu peneliti menutup pembelajaran dengan doa dan mengucapkan salam.

b. Tahap Observasi

Berdasarkan pengamatan peneliti, hasil observasi dan diskusi dengan observer, pada siklus II proses pembelajaran sudah berjalan sesuai dengan skenario meskipun masih belum maksimal. Hasil dari evaluasi nantinya akan tergantung dari masingmasing individu. Adapun hal-hal yang mendukung proses pembelajaran pada siklus II adalah siswa dapat menyeleseikan permasalah kehidupan sehari-hari pada materi himpunan.

Tabel 3. Hasil Minat Belajar Mahasiswa Siklus II

\begin{tabular}{lcc}
\hline Keterangan & Jumlah & Persentase \\
\hline Sangat Tinggi & 15 & $25,42 \%$ \\
\hline Tinggi & 32 & $54,24 \%$ \\
\hline Sedang & 12 & $20,34 \%$ \\
\hline Rendah & 0 & $0 \%$ \\
\hline Sangat Rendah & 0 & $0 \%$ \\
\hline
\end{tabular}

Dari tabel di atas, terlihat bahwa minat belajar mahasiswa pada katagori sangat tinggi memiliki persentase $31,81 \%$, kategori tinggi memiliki persentase $54,24 \%$ dan katagori sedang memiliki persentase $20,34 \%$.

c. Tahap Refleksi

Karena indikator kinerja yang peneliti tentukan sudah tercapai dari segi prestasi belajar dan minat belajar mahasiswa maka dapat dikatakan penelitian ini sudah berhasil, sehingga penelitian dicukupkan sampai siklus II.

\section{Kesimpulan}

Berdasarkan hasil penelitian dan pembahasan, maka dapat disimpulkan bahwa minat belajar mahasiswa mengalami peningkatan untuk kategori sangat tinggi terjadi peningkatan sebesar $87,5 \%$, untuk katagori tinggi terjadi peningkatan sebesar $128,57 \%$. sedangkan untuk kategori sedang dan rendah mengalami penurunan menerapkan pembelajaran PBL pada materi himpunan kelas C Semester I tahun ajaran 2016/1017 PGSD UAD.

\section{Saran}

Sebagai tindak lanjut dari hasil penelitian ini dapat dikemukakan bahwa pembelajaran matematika menggunakan pembelajaran PBL dapat meningkatkan rasa minat belajar siswa, sehingga disarankan bagi pengajar untuk menerapkan pembelajaran ini di dalam kelas.

\section{Daftar Acuan}

Arends, 2008, Learning to Teach-Belajar untuk Mengajar, Pustaka Belajar, Yogyakarta. (penerjemah Soetjipto, dkk).

Collette, A. T. \& Chiappetta, E. L. 1994. Science instruction in the middle and secondary schools. NewYork: Macmillan.

Elliot, S.N, et al. 2000. Educational Psychology: Effective Teaching, Effective Learning. Singapore: Mc Graw-Hill Book .

Hilgard, E. R. 1991. Pengantar Psikologi, Edisi Kedelapan, Jilid 2 . Alih Bahasa: Widjaja Kusuma. Jakarta: PT. Erlangga.

Nana Syaodih Sukmadinata. 2011. Metode Penelitian Pendidikan. Bandung: PT Remaja Rosdakarya. 
Rivai dan Sylviana Murni. 2010. Education management. Jakarta: Rajagrafindo Persada.

Tan, Oon-Seng. 2003. Problem Based Learning Innovation: Using Problems to Power Learning in the $21^{\text {st }}$ Century. Thomson. 